\title{
CONSIDERAÇÕES SOBRE NORMATIVIDADE E ESCOLHA DE SENTIDO EM SARTRE
}

\author{
Cristina Moreira Jalil ${ }^{1}$
}

RESUMO: A realidade humana é apresentada por Sartre como liberdade e indeterminação, o que implica dizer que não podemos contar com definições ou determinações a priori, mas que, na medida em que existimos, devemos nos fazer. Tomando como ponto de partida essa concepção da condição humana de liberdade, questionamos como é possível a essa existência livre movimentar-se em um mundo repleto de regras e orientações. Assim, nesta comunicação, nos propomos tomar como base o pensamento sartreano para refletir sobre o modo como nos relacionamos com valores e demais referências de teor normativo. Sartre afirma que nenhum imperativo, regra ou moral pode determinar de modo causal nossas ações e, dessa forma, cabe a nós sermos legisladores de nós mesmos. Buscaremos apresentar o modo como isso se dá. Em tempos como o nosso, em que voltam a ganhar força e espaço movimentos e discursos moralizantes e normatizadores, que visam fixar valores, normas e verdades universais e absolutas, torna-se relevante a retomada de 
pensadores que, como Sartre, buscaram afirmar e resgatar nossa condição de liberdade e o caráter de agente da nossa própria história - tanto coletiva, quanto individual.

PALAVRAS-CHAVE: Sartre; Normatividade; Sentido.

ABSTRACT: Human reality is exposed by Sartre as freedom and indetermination, which means that we cannot rely on $a$ priori definitions or determinations, but, as we exist, we must make ourselves. Taking as a starting point this conception of the human condition of freedom, we ask how is possible to this free existence to move in a world full of rules and guidelines. Thus, in this paper, we propose to reflect on the sartrean understanding of how we relate to values and other normative content references. Sartre affirms that no rule, imperative or moral could determine causally our actions and it is up to us to be ourselves legislators. We aim to show how it happens. In times like ours, in which movements and moralizing speeches return to gain strength and space, trying to set universal and absolutes truths, values and norms, becomes relevant the resumption of thinkers like Sartre, who sought to affirm and rescue our condition of freedom and the agent character of our own history - both collective and individual.

KEYWORDS: Sartre; Normativity; Sense. 
Muitos leitores de Sartre têm seu primeiro contato com a obra do filósofo através da conferência "O existencialismo é um humanismo" (2013), proferida em 1945 e publicada no ano posterior. Dentre os diversos aspectos da sua filosofia que o autor toca ao longo dessa conferência, interessa-nos aqui, particularmente dois deles: sua concepção do humano que dispensa estruturas, categorias, uma natureza ou essência a priori, e, atrelado a isso, a compreensão de que os valores, os sinais e as referências, ao contrário de determinar as nossas escolhas e ações, dependem do sentido que lhes damos. Trata-se, sem dúvida, de uma colocação inquietante que inaugura uma série de questões $\mathrm{e}$ desdobramentos. A proposta desse texto é a de, partindo da compreensão de Sartre acerca da realidade humana, tecer algumas considerações sobre o modo como nos relacionamos com os valores e outras referências de teor normativo. Para tanto, dialogaremos, basicamente, com a conferência mencionada e a principal obra do filósofo, "O Ser e o Nada” (2007), publicada pela primeira vez em 1943.

\section{SOBRE A REALIDADE HUMANA}

Segundo Sartre, não há qualquer coisa que possa nos definir ou determinar em nossa existência. Ao dizer, por exemplo, que somos consciência e liberdade, o filósofo está 
se referindo à condição da existência humana, já que, na medida em que existimos, somos consciência e liberdade. Entretanto, isso em nada determina o modo como cada existência se fará. Diferentemente dos objetos que produzimos e utilizamos, nós não possuímos a priori nenhuma função ou utilidade. Não fomos feitos para um propósito específico. Todo motivo, razão ou sentido da existência é, como veremos, criado, inventado e escolhido pelo existente no curso da própria existência. Assim, nenhuma natureza, estrutura ou conceito precede nossa existência, pois somos nada inicialmente, "o homem existe primeiro, se encontra, surge no mundo, e se define em seguida [...] e será aquilo que ele se tornar" (SARTRE, 2013, p. 19), aquilo que fizer de si mesmo, através das ações e engajamento no mundo.

Contudo, dizer que nos fazemos ao longo da nossa existência não significa dizer que vamos nos constituindo, nos moldando como uma personalidade, uma essência ou um "eu" mais ou menos definido. Para Sartre, pelo nosso modo de ser, não nos é possível alcançar nada de fixo, permanente ou substancial. Essa compreensão é esmiuçada pelo filósofo ao longo da obra "O Ser e o Nada", através de diversos elementos nos quais não nos deteremos aqui. Todavia, é importante lembrar que ele se inspira na fenomenologia de Husserl e em sua concepção de consciência intencional, ou seja, a concepção de que toda 
consciência é sempre necessariamente consciência de algo. Nessa perspectiva, a consciência é um constante movimento de "voltar-se para"; um deslizamento para fora de si, um arrancar-se de si mesmo. Por ser intencionalidade, por ser sempre consciência de algo, ela em si mesma é um nada. Não há consciência "pura", sem objeto, não podemos captála ou isolá-la objetivamente. E assim não consiste em um espaço, um lugar a ser preenchido por conteúdos, mas existe e se esgota em ser consciência de mundo. A consciência é pura existência, é agente de experiências concretas, um absoluto não-substancial.

Desse modo, somos aquilo que fazemos de nós mesmos, através das nossas ações e engajamentos concretos no mundo, sem entretanto, jamais alcançar uma substancialidade, uma totalidade fechada e constituída. Por não existir nada a priori, uma estrutura ou essência - seja em um nível coletivo, como uma "natureza humana”, ou individual, como um "eu", um caráter ou personalidade definidos - por não haver nada que nos indique, nos determine no que devemos ser, por não termos uma finalidade ou utilidade pré-concebida - diferentemente das coisas e utensílios - que temos que nos fazer em lugar de simplesmente ser. É nesse sentido que Sartre fala que somos condenados a sermos livres, pois, uma vez que existimos, precisamos nos fazer, nos inventar e nos escolher nos mínimos detalhes. Nada nos determina a nos fazermos no 
modo como nos fazemos, o fundamento último das nossas ações é a nossa própria liberdade e, assim, ao longo da existência, precisamos nos inventar, criar e escolher: para a realidade humana, "ser é escolher-se" (SARTRE, 2007, p. 545).

$\mathrm{Na}$ medida em que estamos nos referindo recorrentemente à ação, se faz preciso esclarecer algumas especificidades sobre sua dinâmica na visão sartreana. Sartre certamente se distancia das explicações causais e deterministas da ação. Para ele, todo ato é intencional, ou seja, toda ação e engajamento implica no posicionamento de um possível, um projeto, um fim, algo que não é, não existe ainda. E é sempre à luz desse projeto, fim ou possível que qualificamos nossa situação atual, qualificamos algo como motivo para a nossa ação ou escolha. O motivo, então, afirma Sartre, só aparece como tal a partir de uma consciência de motivo que lhe confere significação $\mathrm{e}$ importância. Mas isso não significa que o projeto ou o fim é a causa das nossas ações. Primeiramente, porque somos nós que escolhemos e posicionamos nossos projetos livremente. Em outras palavras, significa que não há nada que determine quais serão nossos projetos, não existe um destino pré-concebido. Há, em contrapartida, um caminho sendo traçado.

Além disso, o projeto não causa a ação porque não é anterior a ela. Pelo contrário, é na própria ação que nos 
engajamos em um determinado projeto, que estabelecemos e escolhemos nossos fins. Não há primeiro o posicionamento de um projeto para depois eleger os motivos e então agir. Todos esses são elementos integrantes de uma totalidade que se constitui no próprio ato. Estar engajado no mundo é sempre estar, também, realizando projetos. Como já dissemos, não há como desatrelar - ou até mesmo diferenciar - $o$ agir do escolher. A ação expressa nossas escolhas e fins: ao agirmos, estamos escolhendo um projeto, tendo ele sido objeto de uma reflexão ou não.

\section{AÇÃO, ESCOLHA E CRIAÇÃO DE SENTIDO}

A esta altura, cabe questionar: escolha de que? Não se trata simplesmente de escolher ir por aqui ou por ali, fazer isso ou aquilo, mas trata-se do sentido, do peso e do lugar de cada coisa, cada experiência, cada detalhe em nossa existência. Nossa leitura da obra de Sartre nos encaminha para uma compreensão de que nos fazemos e nos escolhemos em termos de sentido. Dito de outra forma, entendemos que, na medida em que existimos, agimos e nos engajamos no mundo, abre-se um campo de sentido, o mundo aparece e se organiza de determinado modo, no qual as atividades, as referências, nós mesmos e os outros, tudo aparece e se articula nessa totalidade com um sentido, 
lugar, peso e importância. $\mathrm{O}$ sentido, tal como estamos nos referindo aqui, diz respeito à razão, o valor, o peso e o lugar que cada um, ao longo de sua existência, confere às experiências passadas, ao mundo, aos valores, às leis, às normas, aos imperativos e à própria existência enquanto totalidade em curso. E a denominamos "em curso" porque não chega a se completar ou definir. $\mathrm{O}$ modo como essa totalidade se constitui, ou seja, como o mundo se organiza e os sentidos com os quais cada elemento aparece não são determinados por nada, eles têm como fundamento nossa liberdade.

É indispensável fazer uma ressalva sobre as noções de escolha e liberdade na ontologia sartreana. No pensamento do filósofo, diferentemente da tradição, ambas não se referem à vontade, à deliberação ou à reflexão. Em resumo, liberdade não significa onipotência, ser livre de barreiras e limitações, ou ser livre para fazer e obter o que se quer. Nada determina, nem a situação em si mesma, nem o meu inconsciente, meu passado, as normas, nada determina que eu aja e escolha, ou seja, que eu me faça do modo como me faço, "ser livre é ser livre de determinação pelo que é" (MORRIS, 2009, p. 178). A escolha, por sua vez, não se refere a uma decisão deliberada, proveniente de reflexões, ela não se distancia da ação- como dissemos, mas é o próprio engajamento através das ações. Conforme agimos, nos engajamos em uma determinada visão de mundo e 
assim escolhemos os sentidos através dos quais o mundo aparece para nós. Mas, essa escolha se expressa no próprio agir. Por nada nos determinar nossas ações, no modo como nos fazemos, por ser a liberdade o único fundamento das ações, estas consistem em escolhas. E é sempre à luz dos projetos, fins e possíveis posicionados que qualificamos nossa situação atual, qualificamos algo como motivo para a nossa ação. Estar engajado no mundo é sempre estar, também, realizando projetos e, ao agirmos, os escolhemos, seja colocando-os como objetos de uma reflexão ou não.

Ao agir não escolhemos apenas um projeto e os motivos relacionados a esse ato. A cada ação empreendida escolhemos a nós mesmos e o nosso mundo. Seja nos mantendo em um mesmo projeto-ou alterando-o parcial ou completamente, a totalidade que somos aparece e é captada por nós a partir do projeto no qual nos engajamos:

Pois bem: a significação do passado acha-se estreitamente dependente do meu projeto presente. Não significa, de forma alguma, que eu possa variar conforme meus caprichos os sentidos dos meus atos anteriores, mas sim que, muito pelo contrário, o projeto fundamental que sou decide absolutamente acerca da significação que possa ter para mim e para os outros o passado que tenho-de-ser. Com efeito, só eu posso decidir a cada momento sobre o valor do passado: não é discutindo, deliberando e apreciando 
em cada caso qual a importância de tal ou qual acontecimento anterior, mas sim projetando-me rumo aos meus objetivos, que preservo o passado comigo e decido por meio da ação qual o seu sentido. (SARTRE, 2007, p. 612).

Ainda que neste trecho Sartre se refira aos eventos passados, essa dinâmica na qual, através da ação, nos engajamos em um projeto e decidimos o sentido, refere-se à existência como um todo, pois o projeto ilumina não apenas o passado, mas nosso ser, nossas existências, compromissos e nosso mundo.

Mas não criamos ou inventamos um mundo "do nada”. A consciência, vimos rapidamente, é sempre voltada, direcionada para um objeto, para o mundo. Sua existência é possível enquanto consciência de alguma coisa - ou se desvaneceria em puro nada. Assim também ocorre com a liberdade, ela só é possível, afirma Sartre, em um mundo que lhe resiste. Isso quer dizer que existimos em uma determinada contingência a qual, a princípio, não escolhemos, e encontramos resistências e obstáculos os quais-aparentemente não criamos. Trata-se do nosso lugar, nosso corpo, nosso passado, com todos os acontecimentos longínquos ou recentes, família e amigos, os outros e a posição em que nos colocam, nossa cultura, linguagem e costumes, nossa cidade, vizinhança, nosso emprego, as 
coisas que utilizamos e nossos atos. Em suma, tudo que envolve nosso existir, todo o nosso entorno, assim como nós mesmos.

Certamente não escolhemos, antes de existirmos, a cidade onde nasceremos, nossa cultura, nossos corpos e famílias. São fatos de pura contingência. Sobre isso, Sartre (2007, p. 693) coloca:

Bem mais do que "fazer-se", o homem parece "ser feito" pelo clima e a terra, a raça e a classe, a língua, a história da coletividade da qual participa, a hereditariedade, as circunstâncias individuais de sua infância, os hábitos adquiridos, os grandes e pequenos acontecimentos de sua vida.

Tudo aquilo que não escolhemos e que, no entanto, nos constitui e temos de ser, Sartre denomina "facticidade". Esses aspectos são um fato, dado "bruto": nosso corpo, a cidade em que nascemos, a família e a cultura a qual pertencemos, a posição econômica e social em que nos encontramos, entre tantas coisas mais quanto possamos pensar. Contudo, nada disso existe simplesmente como fato ou dado, pois nós existimos, isso--no sentido de que vivenciamos, experienciamos isso. Nas palavras de Sartre, somos tudo isso que existe como nossa contingência. Assim, podemos dizer que, de certa forma, escolhemos a nossa 
facticidade na medida em que temos de sê-la de algum modo e este modo não é dado de antemão, nem é determinado por nada, tendo como fundamento a própria liberdade. Ainda que a contingência tenha seu aspecto factual, bruto, dado, isso não determina a maneira como tudo isso será organizado, significado, como aparecerá e estará em jogo. Não significa que somos indiferentes à nossa contingência, pois tudo isso nos constitui e nós temos de ser, ainda que não queiramos, mas o modo como nos relacionaremos com isso se constitui ao longo da nossa existência através das nossas ações e engajamentos, ele não está dado e nem mesmo se cristaliza, é sempre aberto, dinâmico, "em jogo".

Quem decidirá se aquela crise mística por que passei aos quinze anos "foi" puro acidente de puberdade ou, ao contrário, primeiro sinal de uma conversão futura? Eu mesmo, desde que decida - aos vinte ou trinta anos - converter-me. O projeto de conversão confere de uma só vez a uma crise de adolescência o valor de uma premonição antes não levada a sério. Quem decidirá se minha estada na prisão, depois de um furto, foi frutuosa ou deplorável? Eu mesmo, conforme venha a desistir de roubar ou me manter incorrigível. Quem pode decidir sobre o valor educativo de uma viagem, a sinceridade de um juramento de amor, a pureza de uma intenção 
passada, etc.? Eu mesmo, sempre eu, conforme os fins pelos quais ilumino esses eventos passados. (SARTRE, 2007, p. 612-13).

Assim, nada disso aparece em bruto, mas sempre significado à luz de um projeto na medida em que nos engajamos no mundo. Tudo isso só tem sentido, diz Sartre, na e pela livre escolha que a realidade humana é. É nesse sentido que o filósofo afirma que somos liberdade em situação. A situação é, nas palavras de Sartre (2007, p. 600), "produto comum da contingência do Em-si e da liberdade, é um fenômeno ambíguo, no qual é impossível ao Para-si discernir a contribuição da liberdade e a do existente em bruto". Em suma, tudo aquilo que nos constitui, nossa facticidade, aparece-nos com um determinado sentido articulado dentro dessa totalidade e desse projeto que cada um de nós é.

[...] o passado só é aquilo que é em relação ao fim escolhido. Há no passado um elemento imutável: tive coqueluche aos cinco anos de idade; e há um elemento variável por excelência: a significação do fato em bruto com relação à totalidade de meu ser. Porém, por outro lado, uma vez que a significação do fato passado penetra nesse passado de ponta a ponta ([já que] não posso "recordar" minha coqueluche de infância à parte de um projeto preciso 
que define sua significação), é impossível para mim, em última instância, distinguir a imutável existência em bruto do sentido variável que ela comporta. (SARTRE, 2007, p. 612).

$\mathrm{Na}$ medida em que me engajo, todo o mundo, tal como aparece para mim, se objetiva, se naturaliza. $O$ sentido se concretiza. É preciso uma mudança radical de um projeto de sentido total para que haja quebra e rearticulação de sentido desse mundo. As coisas que nos rodeiam e o modo como elas se organizam em um mundo anunciam para nós o que somos. Tudo ganha sentido a partir das escolhas e ações e, dessa forma, o mundo não aparece desinteressado, pelo contrário, tudo tem um lugar, um sentido. Dito de outro modo, ao agir, organizamos um mundo de significados que é o meu, no qual as coisas aparecem para mim como minhas coisas. No entanto, uma vez que minha escolha é feita, este mundo se organiza, se concretiza, e, por isso, não seria correto dizer que os sentidos colocados a partir das escolhas são relativos, que podem mudar a qualquer momento, por capricho ou de acordo com a minha vontade. Os significados aparecem em função de um campo de atividade que organiza um campo de sentido, e não pela vontade ou reflexão. É claro que a cultura à qual pertenço, os fatos passados, os compromissos que assumo, o mundo como um todo tem certa objetividade 
que independe de mim. Mas, na medida em que existo e que isso me "vem ao encontro" e me constitui, tudo isso está em jogo para mim e é para mim que isso aparece de um determinado modo, com um determinado sentido.

Assim, todo o meu passado está aí, insistente, urgente, imperioso; mas escolho seu sentido e as ordens que me dá pelo próprio projeto de meu fim. Sem dúvida, os compromissos que assumi pesam em mim; sem dúvida, o vínculo conjugal outrora assumido, a casa comprada e mobiliada no ano passado limitam minhas possibilidades e ditam minha conduta; mas isso ocorre precisamente porque meus projetos são de tal ordem que reassumo o vínculo conjugal, ou seja, precisamente porque não projeto a recusa desse vínculo, porque não o transformo em "vínculo conjugal passado, ultrapassado, morto", mas sim porque, ao contrário, meus projetos, ao encerrar a fidelidade aos compromissos assumidos ou a decisão de levar uma "vida honrosa" de marido e de pai, etc., vêm necessariamente iluminar o juramento conjugal passado e conferir-lhes seu valor sempre atual. (SARTRE, 2007, p. 613).

Um ponto importante nesta citação diz respeito às desculpas e justificativas que muito comumente utilizamos. 
Costumamos explicar nossa situação, nossas ações ou escolhas, e até mesmo nosso ser a partir de acontecimentos passados. Dizemos que somos assim por termos sofrido uma situação traumática ou por termos sido criados dessa maneira, ou até mesmo porque nos acostumamos a ser desse modo. Para Sartre, como vimos, o passado existe enquanto fato, não podemos mudar os eventos ocorridos, $o$ passado nos constitui e faz parte da nossa facticidade. Mas, tal como todo o resto, o modo como os acontecimentos passados aparecem para nós é sempre dotado de um sentido que por sua vez está ligado à nossa situação presente e ao projeto futuro no qual estamos engajados. Dessa maneira, a decisão do sentido de um evento passado - assim como dos sinais, valores e normas - é tomada pelo existente. Mesmo a nossa situação atual e o porvir, tudo isso aparece para nós com sentidos articulados em uma totalidade que está perpetuamente se fazendo.

Com efeito, a continuidade da existência, processo que nunca se completa, pois nunca atinge a totalidade, deve ser entendida como as opções subjetivas que se sucedem no tempo da existência, aquele em que o sujeito assume a cada momento seu passado, atribuindo-lhe um sentido, e se projeta no futuro a partir da liberdade em que se reconhece no presente. (SILVA, 2010, p. 22). 
Outro ponto importante presente na nossa última citação de Sartre diz respeito à limitação das nossas possibilidades. Ora, é claro que viver em uma cidade litorânea me proporciona muito mais possibilidades de ir à praia do que alguém que viva no centro do país. Mas é importante notar que ter oportunidades de ir à praia só é uma questão, só aparece como uma restrição ou não para alguém que tem como finalidade ir à praia, que goste, que deseje, que planeje isto. Viver longe do mar, para alguém que não gosta de praia-não é uma restrição, uma limitação, assim como morar perto da praia não é uma vantagem para quem não coloca um dia na praia como possibilidade. No fim das contas, a restrição ou não está sempre inserida no protejo, na existência singular de cada um.

O coeficiente de adversidade das coisas, em particular, não pode constituir um argumento contra nossa liberdade, porque é por nós, ou seja, pelo posicionamento prévio de um fim, que surge o coeficiente de adversidade. [...] Assim, ainda que as coisas em bruto [...] possam desde a origem limitar nossa liberdade de ação, é nossa liberdade mesmo que deve constituir a moldura, a técnica e os fins em relação aos quais as coisas irão manifestar-se como limites. Mesmo se o rochedo se revela como "muito difícil de escalar" e temos de desistir da escalada, observemos que ele só se revela desse modo por ter 
sido originariamente captado como "escalável" (gravissable); portanto, é nossa liberdade que constitui os limites que irá encontrar depois. (SARTRE, 2007, 593-94).

A contingência em si mesma, seja ela atual ou passada, não impõe um sentido, nem uma ação. Não aparece como obstáculo ou barreira em si mesma, mas apenas dentro do projeto, da nossa finalidade. Assim, nossa facticidade nos constitui, mas não nos determina em nosso comportamento, em nossa existência. Pois isso significaria dizer que nosso caminho, nossa história e nossa existência já estão traçados de antemão, seria pensar em algo como um destino. Significaria dizer que todos aqueles imersos em uma mesma cultura, uma mesma família ou classe social são iguais e têm um mesmo destino. Que são meros produtos da conjuntura, que são passivos - e não agentes. Significaria, ainda, dizer que a conjuntura e o contexto no qual vivemos não podem ser modificados. Assim, por exemplo, nascendo em uma sociedade machista, seríamos meros produtos e reproduções dessa sociedade, não poderíamos questioná-la e sequer seria possível apreendê-la como machista.

$\mathrm{Na}$ medida em que não estamos dados de antemão, mas devemos nos fazer, a cada momento, sem que nada nos determine ou direcione no modo como nos fazemos e nos escolhemos, podemos dizer que o nosso ser está sempre “em 
jogo", sempre em questão para nós mesmos, como mostra Leopoldo e Silva (2010, p. 20-21):

A descrição ontológica que Sartre faz da subjetividade por via da fenomenologia tem como finalidade elucidar a condição humana. Ainda assim é preciso dizer que essa condição da qual está por princípio ausente qualquer determinação essencial, configura-se como uma questão. O homem só pode ser definido como uma questão para si mesmo: não há respostas em termos de determinação de essência e não há respostas em termos de uma configuração da condição existencial que se pudesse tomar como definitiva. A compreensão da existência é a elucidação de um processo, entendido como um movimento de totalização constitutivamente inacabado.

Ora, se devemos escolher os sentidos da nossa existência, é isso que está em jogo e se apresenta como questão na existência: não há sentidos pré-determinados e devemos, continuamente, inventá-los, criá-los, escolhê-los, retomá-los. Assim, cada um de nós, ao surgir no mundo, depara-se com sua existência enquanto uma questão, para a qual não há respostas prévias, mas que devem ser criadas e inventadas por nós mesmos. Até mesmo as respostas e prescrições oferecidas pelo mundo, que estariam 
supostamente prontas e seriam impostas, essas só se sustentam como tais na medida em que cada um-as assume dessa maneira. A “resposta” à questão que nós somos é a própria existência no modo como vai se dando concretamente para cada um de nós, como coloca Sartre (2007, p. 570):

Meu projeto último e inicial [...] é sempre, como veremos, o esboço de uma solução do problema do ser. Mas esta solução não é primeiro concebida e depois realizada: somos esta solução, fazemo-la existir pelo nosso próprio comprometimento e, portanto, só podemos captá-la vivendo-a.

Destarte, criando e escolhendo os sentidos, criamos nossa história, escolhemos a nós mesmos. $\mathrm{E}$ isso só pode acontecer na ação, no engajamento no mundo. Embora, a princípio, não possamos escolher o que se dá em nossa existência, em termos de acontecimentos factuais, estamos condenados a continuamente escolher e decidir o sentido que isso terá para nós, como isso se articula a cada vez na totalidade da nossa existência. E, assim, podemos marcar o caráter inventivo e interpretativo da existência humana.

Mas dizer que o nosso ser está sempre em jogo e em questão, não significa apenas que de início somos nada e, portanto devemos nos fazer, pois a nós nunca é possível 
alcançar a substancialidade e totalidade completa. Nosso ser está em jogo, sobretudo porque o nada que nós somos está sempre "inundando" o ser, o projeto em que nos engajamos e que ilumina e dá sentido a nós e ao nosso mundo é sempre projeto de uma liberdade. E a liberdade ameaça-o. Isso significa que não há garantias, pois, sendo liberdade devemos, a cada vez, em cada ato, retomar todos os motivos e sentidos articulados para aquela decisão, aquele projeto, $\mathrm{e}$ sustentá-lo - ou abandoná-lo. Pela própria condição de ser liberdade nossas escolhas e projetos estão sendo sempre retomados, sustentados ou negados, ressignificados.

[...] jogador que livre e sinceramente decidiu parar de jogar e, ao aproximar-se do "tapete verde", vê "naufragarem" suas decisões. [...] o que o jogador capta neste instante é a ruptura permanente do determinismo, o nada que o separa de si mesmo: eu tinha desejado tanto não jogar mais que, ontem mesmo, tive uma apreensão sintética da situação (ameaça de ruína, desespero de meus parentes) como algo que me proíbe de jogar. Parecia-me ter criado assim uma barreira real entre o jogo e mim, mas eis que - percebo de repente - essa apreensão sintética não passa de recordação de uma ideia, lembrança de um sentimento: para que aquela decisão venha de novo me prestar ajuda, é preciso que eu a refaça ex nihilo e livremente; é apenas um de 
meus possíveis, assim como o fato de jogar é outro, nem mais nem menos. (SARTRE, 2007, p. 77).

Dessa forma, a partir da significação, do movimento de dar sentido, podemos compreender a relação que estabelecemos com o mundo compartilhado (com toda sua "objetividade" e imposições de estruturas, normas, valores, leis etc.), com nós mesmos e nossos projetos. Aproximando-nos do caminho traçado por Sartre em suas obras, podemos compreender melhor que, sem negar o mundo ou estabelecer uma primazia da vontade ou da racionalidade humana, ele propõe uma compreensão do modo de ser da realidade humana que foge às concepções deterministas que insistem em explicar o homem por meio de causa e efeito.

Com essa compreensão, Sartre aponta para nossa responsabilidade diante da existência, já que estamos "desamparados, sem ajuda ou desculpas", pois o sentido, o significado, o peso, a razão e o lugar daquilo que acontece ao longo da existência deve ser eleito por nós. No início de sua conferência de 1945, por exemplo, Sartre retoma a história bíblica de Abraão, que foi ordenado por Deus a sacrificar seu filho. Ele utiliza o exemplo para apontar que coube a Abraão, bem como cabe a cada um de nós, escolher e decidir o sentido da ordem que lhe foi dada. Como distinguir essa situação, acrescenta Sartre, de uma mulher 
que tem alucinações auditivas de Deus dando-lhe ordens? Que provas temos de que essas vozes "provêm do céu e não do inferno, ou do subconsciente, ou de um estado patológico?" (SARTRE, 2013, p. 24). Não interessa-nos aqui definir qual a natureza de tais vozes, de onde vêm, se verdadeiras ou não, mas sim trazer a tona o que o filósofo nos mostra com tais situações: o poder de tais ordens e vozes, o lugar e o peso que elas assumem na existência de cada um que as escuta, o seu sentido dependem daquele à quem elas se dirigem, dependem de sua escolha e decisão.

A revelação dessa condição que é a nossa, de indeterminação, liberdade e responsabilidade por nossa existência, se dá através da experiência da angústia, como mostra Leopoldo e Silva (2010, p. 22):

Não há nada, na origem ou por trás do processo existencial, que faça as vezes de fundamento ou de elo de articulação que pudesse dar a esse vir-a-ser um sustentáculo em que a trajetória subjetiva viesse a transcorrer como em um solo firme. Aliás, já na primeira novela de Sartre, $A$ náusea, o que incomoda a personagem, o que lhe provoca a náusea, é esse caráter solto das coisas e dele mesmo, essa existência sem causa, essa gratuidade que nos impede de medir o mundo por parâmetros encadeados de origem e de fim. Não há nada que assegure de antemão que a existência surge a partir de algo e se encaminha para 
algo, e que o seu sentido estaria precisamente constituído entre o princípio e a finalidade. $\mathrm{Na}$ ausência desse lastro de significação, tudo oscila, tudo se torna imprevisível e angustiante.

Com esse trecho parece se esclarecer que aquilo que aparece para nós como mundo, como realidade é escolha de sentido e significações desse mundo, dessa realidade, da nossa facticidade. Dizer que nosso ser está sempre em jogo significa sobretudo que, por sermos liberdade, os projetos nos quais nos engajamos e os sentidos que nos aparecem de modo tão naturalizado e objetivo estão sempre "ameaçados" por nossa liberdade. A escolha e o engajamento em um projeto, em um mundo de sentido não garante sua continuidade e sustentação, pois somos nós, enquanto liberdade, que devemos, a cada vez sustentá-los, reassumilos ou negá-los. E a captação disso tudo a partir da angústia é a captação mesma da nossa condição de indeterminação, injustificabilidade, de desamparo, de ser sem desculpas.

[...] na angústia, não captamos simplesmente o fato de que os possíveis que projetamos acham-se perpetuamente corroídos pela nossa liberdade-porvir, mas também apreendemos nossa escolha, ou seja, nós mesmos, enquanto injustificável, isto é, captamos nossa escolha como algo não derivado de qualquer realidade anterior e, ao contrário, como 
algo que deve servir de fundamento ao conjunto das significações que constituem a realidade. A injustificabilidade não é somente o reconhecimento subjetivo da contingência absoluta de nosso ser, mas ainda $o$ da interiorizaçao desta contingência e reassunção por nossa conta. (SARTRE, 2007, p. 5723).

Porém, em geral nossa conduta e relação com os valores é tranquilizadora. Comprometemos-nos, assumimos e escolhemos um mundo de valores e sentidos já dados e vivemos como se estes nos determinassem e nos limitassem, dissimulando o fato de que somos nós quem os escolhemos como nossos valores e sentidos. Em algumas passagens Sartre se refere a isso como "espírito de seriedade" - expressão que ele utiliza especialmente para criticar os "valores burgueses" -, o qual "capta os valores do mundo e reside na substancialização tranquilizadora e coisista dos valores" (SARTRE, 2007, p. 84). Trata-se da tentativa de nos captarmos como uma identidade, como algo fechado e determinado pelo mundo, tornando nossos atos puro efeito, pura causalidade e necessidade. Ou seja, trata-se da tentativa de evitar depararmo-nos e assumirmos o caráter de indeterminação, de possibilidade e abertura, que implicam o nosso modo de ser, que é liberdade e 
consciência. O filósofo aprofunda essa questão através do conceito de má-fé, que não abordaremos neste escrito.

\section{SENTIDO E NORMATIVIDADE}

É nesse panorama que colocamos em questão a relação que estabelecemos com as referências de teor normativo. Ora, nosso esforço em mostrar a existência humana em uma relação de sentido, de significação, qualificação e valoração do mundo temcomo intenção mostrar que não ocorre diferentemente com as referências normativas. Na medida em que "a existência é movimento de (auto)constituição, e não solo firme em que se poderiam plantar alicerces morais" (SILVA, 2010, p. 21), toda moral, todos os valores devem ser inventados, criados ou reassumidos com certo sentido dentro da totalidade daquela existência particular. Em resumo, significa que devem ser escolhidos. Na medida em que somos nós quem decifra, quem escolhe o sentido - o significado, o peso, o lugar, a razão e o poder - de um sinal ou regra, Sartre (2013, p. 28) afirma: "Nenhuma regra de uma moral genérica pode indicar o que devemos fazer; não existem sinais outorgados no mundo".

Apenas pode existir um código moral - um sinal, uma norma ou regra - na medida em que elegemos um. Com 
isso, o filósofo mostra-nos que não há valores, referências ou orientações nas quais possamos nos basear para agir e que legitimem nossas ações. Alguém dirá, com razão, que não nos faltam instituições - tais como a igreja, a ciência, a família e a cultura - que nos orientem acerca do que é certo ou errado, do que ou como se deve ou não fazer, agir e existir. Mas contra-argumentaremos: essas referências apenas têm peso normativo na medida em que as assumimos a cada vez como necessárias a serem seguidas, como legítimas e importantes, como nossas. Elas tampouco estão inscritas em um "céu inteligível", determinadas por uma divindade ou naturalmente estabelecidas, mas são criadas e mantidas, coletiva e individualmente, por nós através da História:

Ora, o homem não é um ser isolado, mas eminentemente um ser-em-situação produzindo a si mesmo (e o mundo) dentro de um contexto sóciohistórico de sentidos e de significados sem que, no entanto, ele seja mecanicamente causa (resultado, passividade) dos condicionamentos. (MOURA, 2013, p. 43).

A proposta sartreana é a de pensarmos o humano como um ser histórico, em uma relação dialética com a situação e o mundo histórico que o constitui - e que, reciprocamente, ele também constitui -, mas sem que ele 
seja causado, "produzido", de forma mecânica, determinada e passiva por essa contingência que é a dele. Com isso, Sartre nos coloca em posição de agentes da nossa história, e não meros receptores, reprodutores, à mercê de modelos, discursos, normas e regras.

Com essas considerações, não queremos dizer que não há valores, regras e referências - pois o mundo está cheio deles -, mas que cada um de nós - e, também, juntos, enquanto coletividade -, em nossas vivências concretas, se depara com a necessidade de escolher ou não tais orientações como direcionadoras das nossas ações, da nossa existência. Queremos apontar que os valores $\mathrm{e}$ as referências, sendo negados ou mantidos, não se sustentam por princípios abstratos e autônomos, mas nas relações concretas que mantemos com nós mesmos, com os outros e com o mundo. Se pensarmos os valores, leis e normas como orientações históricas a partir das quais um grupo se organiza, frutos do movimento dialético entre história e consciência, coletividade e indivíduo, concluiremos que consistem em construções humanas, mesmo que "objetivadas", instituídas, "naturalizadas", na medida em que assumidas por uma coletividade. Mas apenas normativas porque assumidas assim por cada um:

[...] as normas, as leis e os valores que serão estabelecidos (negados ou mantidos) na comunidade 
não se sustentam por princípios abstratos (justiça, tradição, cultura, norma, dever) autônomos, mas por relações concretas que ele estabelece consigo, com o outro e com o mundo, interiorizando e (re)exteriorizando tal universo normativo. (MOURA, 2013, p. 49).

Assim, diante dessa compreensão, identificamos como incoerente e equívoca a atitude de tomarmos tais orientações como imperativos aos quais devemos seguir, como verdades absolutas que nos ditam como devemos conduzir-nos, quando os imperativos dependem de nós para serem sustentados como tais. Trata-se de repousar na justificativa de que nada podemos fazer diante das regras do jogo, quando somos nós quem as inventa, cria e sustenta. Nossa intenção aqui não é a de dissolver as normas, leis e orientações, pois elas ocupam seu lugar de importância em uma existência compartilhada e ordenada, e disso carecemos nos tempos complexos em que vivemos. Entretanto, queremos trazer à tona essa dinâmica de nos tornarmos escravos das nossas próprias regras, aprisionando-nos nelas, deixando que elas nos conduzam e não o contrário, esquecendo-nos de que são instrumentos criados por e para nós, supostamente, em nome da ordem e do bem estar geral. Essa discussão deve ser pensada a nível individual e coletivo. Parece-nos que Sartre, a seu modo e 
em relação ao seu mundo histórico, engajou-se- em seus atos e em seu projeto de escrita nessa direção e nos parece que muito disso podemos - e devemos - atualizar para o nosso momento histórico.

A partir dessas colocações, pretendemos mostrar que os imperativos do mundo não podem ser determinantes da existência, não podem agir como causas das nossas ações a menos que nós os apreendamos com esse sentido. Trata-se de uma constatação que retira-nos de uma posição cômoda, pois, partindo dela e levando-a à risca, não podemos justificar nossas ações a partir de valores, normas ou regras, já que eles apenas funcionam de tal modo se assim os escolhemos, se os aceitamos como valores, regras e normas para nós. Nesse sentido, Sartre coloca:

O despertador que toca de manhã remete à possibilidade de ir ao trabalho, minha possibilidade. Mas captar o chamado do despertador como chamado é levantar-se. Assim, o ato de levantar da cama é tranqüilizador, porque evita a pergunta: "Será que o trabalho é minha possibilidade?" [...] Em resumo, na medida em que apreender o sentido da campainha do despertador já é ficar de pé a seu chamado, tal apreensão me protege contra a angustiante apreensão de que sou eu - eu e mais ninguém - quem confere ao despertador seu poder de exigir meu despertar. Da mesma forma, o que se 
poderia chamar de moralidade cotidiana exclui a angústia ética. [...] o valor só pode revelar-se a uma liberdade ativa que o faz existir como valor simplesmente por reconhecê-lo como tal. Daí que minha liberdade é o único fundamento dos valores e nada, absolutamente nada, justifica minha adoção dessa ou daquela escala de valores. Enquanto ser pelo qual os valores existem, sou injustificável. (SARTRE, 2007, p. 82-83).

E conclui, apontando o caráter ativo e responsável de cada um sobre sua existência:

Todas essas pequenas esperas passivas pelo real, todos esses valores banais e cotidianos tiram seu sentido, na verdade, de um projeto inicial meu, espécie de eleição que faço de mim mesmo no mundo. [...] descubro-me de repente como aquele que dá ao despertador seu sentido, que se proíbe, a partir de um cartaz, de andar por um canteiro ou gramado, aquele que confere poder à ordem do chefe, decide sobre o interesse do livro que está escrevendo - enfim, aquele que faz com que existam os valores, cujas exigências irão determinar sua ação. (SARTRE, 2007, p. 84).

Para que sejamos livres para criar, inventar e escolher os sentidos de nós mesmos e do mundo - dos 
valores, das normas, das compreensões, referências e imperativos -, temos como condição que sejamos situados. O sentido escolhido e criado por nós, então, não pode ser abstrato, arbitrário ou voluntarioso, ele é concreto e objetivo. A negação ou nadificação do mundo - e das normas que existem nele - que faz com que ele apareça de um modo particular, de certo ponto de vista, que ele seja captado com certo sentido. Esse sentido ou ponto de vista, por sua vez, necessariamente aparece relacionado com a História e o mundo compartilhado, pois existe em relação a esse mundo do qual é consciência e o qual nadifica.. Nadificar e negar esse mundo é fazê-lo aparecer de certa maneira, com um sentido. No caso das referências normativas, é posicionar-se com relação a elas, escolhendoas como nossas, ou contrapondo-nos a elas - esses são apenas exemplos de uma infinidade de possibilidades.

Deste modo, Sartre mostra-nos que cabe a nós sermos legisladores de nós mesmos, escolhendo, a cada vez, o peso, o poder, o lugar e o significado das normas e valores que nos vêm ao encontro. Em tempos como o que vivemos, em que voltam a ganhar força e espaço movimentos e discursos moralizantes, que visam fixar valores, normas e verdades universais e absolutas, nos parece propícia e relevante a retomada de pensadores que, como Sartre, buscaram afirmar e resgatar nossa condição de liberdade e o caráter de agentes da nossa própria história - tanto coletiva, quanto 
individual. Baseamo-nos na obra de Sartre visando pensar o nosso mundo contemporâneo, suas questões $\mathrm{e}$ problemáticas, o que aponta a atualidade do pensamento do filósofo.

Para nós essa reflexão se mostra de suma importância, especialmente nos dias atuais, em que multiplicam-se os debates acerca dos direitos humanos, da diversidade, das minorias, e que, por outro lado, acompanhamos crescentes tentativas de estabelecer de modo mais rígido e bem delimitado os valores, modelos, referências, as categorias, as normas e definições-como anteriores e originários com relação à existência - o que os tornariam determinantes da nossa existência e das possibilidades de se fazer no mundo. Frente à compreensão da existência humana que acabamos de apresentar, podemos dizer que esses movimentos que se concedem "a sombria permissão de fixar suas normas, seus valores e suas verdades para toda uma sociedade" (SANTOS, 2013, p. 27) parecem esquecer ou querer que esqueçamos o nosso caráter originário de estar sempre em jogo, em questão, e de sermos nós os responsáveis por eleger nossos valores e referências. 


\section{CONSIDERAÇÕES FINAIS}

Buscamos mostrar, com base no pensamento de Sartre, que a realidade humana é responsável por inventar e criar os valores e referências normativas. Ainda que surjamos em um mundo já constituído, repleto de normas, valores, regras, em suma, de referências normativas, procuramos esclarecer que isso não diminui a liberdade humana, pois, como essas referências estarão em jogo para cada um, o sentido delas não está determinado por nada, mas é escolhido. Escolha essa que se expressa nas ações, engajamentos, no caminho traçado. Somos nós que escolhemos as imposições como valores impositivos que deverão nortear as nossas decisões e ações e, ao fazê-lo, escolhemos nosso mundo e a nós mesmos. Sem a nossa escolha, em si mesmas, as imposições sociais e culturais não possuem peso ou valor normativo algum. Na medida em que nossa sociedade se sustenta e se baseia historicamente em princípios e compreensões determinantes - sejam eles biológicos, psicológicos, sociais ou religiosos -, acreditamos que seja indispensável não nos esquecermos desse nosso caráter originário de estar sempre em jogo e em questão para nós mesmos. $\mathrm{E}$, com isso, não nos esquecermos da nossa liberdade e responsabilidade diante desses princípios, do mundo e das nossas existências.

Sabemos da impossibilidade de esgotar a 
complexidade e extensão dos conceitos e das questões colocadas aqui. Esperamos ter conseguido apresentar um panorama geral e inicial da temática e que essas considerações possam suscitar mais debates e discussões que nos parecem indispensáveis. Arriscamo-nos a dizer que, a partir do que expusemos, podemos pensar em extrapolar o famoso dizer de Sartre sobre sermos aquilo que fazemos com o que fazem de nós, para sermos aquilo que fazemos com o mundo que nos rodeia - os objetos, as regras, as significações e referências, nosso passado, nossas experiências e, claro, também, aquilo que o outro faz de nós. O sentido, então, parece ter grande importância para a afirmação e compreensão da realidade humana como liberdade. Sendo livre, se escolhe. E escolhe, através da ação, a si e ao mundo. Escolhe o sentido de si e do mundo. 


\section{NOTAS}

${ }^{1}$ Mestranda em Filosofia pela Universidade Federal da Bahia (UFBA).

E-mail: cristinamjalil@gmail.com.

\section{REFERÊNCIAS BIBLIOGRÁFICAS}

MORRIS, K. J. Sartre. Tradução de Edgar da Rocha Marques. Porto Alegre: Artmed, 2009.

MOURA, C. E. A moral e a dimensão do valor como transcendência: a ipseidade e o grupo social. In: Poros. Uberlândia, v. 2, n. 3, 2010, p. 80-96.

A moral e a historialização como afirmação da liberdade. In: Theoria. Pouso Alegre, v. 3, n. 7, 2011, p. 6388.

- Ética e política em Sartre: os desafios da intersubjetividade. In: Ideação. Feira de Santana, v. 1, n. 27, jan./jun., 2013, p. 33-72.

SANTOS, V. 70 anos depois: o que O Ser e Nada tem a nos dizer ainda hoje?. In: Ideação. Feira de Santana, v. 1, n. 27, jan./jun., 2013, p. 13-31.

SARTRE, J-P. O Existencialismo é um Humanismo. Tradução de João Batista Kreuch. Petrópolis: Vozes, 2013. 
- O Ser e o Nada - Ensaio de Ontologia Fenomenológica. Tradução e notas de Paulo Perdigão. Petrópolis: Vozes, 2007.

SILVA, F. L. Conhecimento e identidade histórica em Sartre. In: Trans/Form/Ação. São Paulo, v. 26, n. 2, 2003, p. 43-64.

- Literatura e experiência histórica em Sartre: o engajamento. In: Dois Pontos. Curitiba, São Carlos, v. 3, n. 2, out./2006, p. 69-81.

. Literatura, ética e política em Sartre. In: Teresa. São Paulo, v. 10/11, 2010, p. 18-28.

SOUZA, T. M. Ética e estética no pensamento de Sartre. In: Estudos Filosóficos. São João del-Rei, n. 4, 2010, p. 84-96.

. Liberdade e determinação na filosofia sartreana. In: Kinesis. Marília, v. 2, n. 3, abril/2010, p. 13-27.

YAZBEK, A. C. A ressonância ética da negação em Sartre (considerações sobre liberdade, angústia e valores em L'être et le neánt). In: Cadernos de Ética e Filosofia Política. São Paulo, v. 7, 2005, p. 141-164. 